Article

\title{
Assessment of Land-Use/Land-Cover Change and Forest Fragmentation in the Garhwal Himalayan Region of India
}

\author{
Amit Kumar Batar ${ }^{1, *}$, Teiji Watanabe ${ }^{2}$ and Ajay Kumar ${ }^{3}$ \\ 1 Graduate School of Environmental Science, Hokkaido University, Sapporo, Hokkaido 060-0810, Japan \\ 2 Faculty of Environmental Earth Science, Hokkaido University, Sapporo, Hokkaido 060-0810, Japan; \\ teiwata@mac.com \\ 3 Department of Geography, Delhi School of Economics, University of Delhi, Delhi 110007, India; \\ mail_kumarajay@yahoo.com \\ * Correspondence: amitbatar.geo@gmail.com; Tel.: +81-80-9615-1552
}

Academic Editor: Yu-Pin Lin

Received: 10 March 2017; Accepted: 17 April 2017; Published: 19 April 2017

\begin{abstract}
The Garhwal Himalaya has experienced extensive deforestation and forest fragmentation, but data and documentation detailing this transformation of the Himalaya are limited. The aim of this study is to analyse the observed changes in land cover and forest fragmentation that occurred between 1976 and 2014 in the Garhwal Himalayan region in India. Three images from Landsat 2 Multispectral Scanner System (MSS), Landsat 5 Thematic Mapper (TM), and Landsat 8 Operational Land Imager (OLI) were used to extract the land cover maps. A cross-tabulation detection method in the geographic information system (GIS) module was used to detect land cover changes during the 1st period (1976-1998) and 2nd period (1998-2014). The landscape fragmentation tool LFT v2.0 was used to construct a forest fragmentation map and analyse the forest fragmentation pattern and change during the 1st period (1976-1998) and 2nd period (1998-2014). The overall annual rate of change in the forest cover was observed to be $0.22 \%$ and $0.27 \%$ in the 1 st period (1976-1998) and 2nd period (1998-2014), respectively. The forest fragmentation analysis shows that a large core forest has decreased throughout the study period. The total area of forest patches also increased from 1976 to 2014, which are completely degraded forests. The results indicate that anthropogenic activities are the main causes of the loss of forest cover and forest fragmentation, but that natural factors also contributed. An increase in the area of scrub and barren land also contributed to the accumulation of wasteland or non-forest land in this region. Determining the trend and the rate of land cover conversion is necessary for development planners to establish a rational land use policy.
\end{abstract}

Keywords: land cover changes; forest fragmentation; Garhwal Himalaya; remote sensing; GIS

\section{Introduction}

Mountains are among the most fragile environments on Earth. Many mountain ecosystems, including the Himalayan mountains, which are among the most unstable and fragile mountain areas in the world, are strongly affected by drivers of global change such as land use changes and climate change [1-6]. Environmental degradation such as deforestation and degradation of the Himalayan forests are major environmental issues of global significance and some of the most intensively studied land use change processes $[1,7,8]$. Despite the fact that the Indian Himalayas are recognized global biodiversity hotspots, forest cover is under pressure from extensive and rapid land cover change due to anthropogenic and natural drivers $[9,10]$. At the same time, the Himalayan region is vulnerable to numerous types of hazards such as landslides, extreme rainfall events, floods, and forest fires, which further deteriorate the mountain landscape and forest ecosystem [11-13]. 
Forest loss and fragmentation are distinct but related phenomena. Forest loss is simply the conversion of forestland to some other land use, but forest fragmentation occurs when a large region of forest is broken down, or fragmented, into a collection of smaller patches of forest habitat [14,15]. Forest landscapes are at high risk of forest fragmentation because of changes in land cover due to processes such as agricultural intensification, logging, and infrastructure development. These changes have led not only to the loss of habitat and biodiversity, but also to the modification of natural landscapes and ecosystem functions [16-21]. The anthropogenic drivers and their impact on natural resources, biodiversity, habitat loss, and fragmentation of the forest are widely documented across the Hindu Kush Himalaya region [22-28], although non-anthropogenic drivers such as natural hazards also contribute to forest fragmentation, especially in mountain regions such as the Himalayas [29]. However, very few studies have been conducted to understand the correlation between natural hazards and forest fragmentation. Therefore, understanding the link between natural hazards and forest fragmentation at different scales is also important for implementing conservation strategies for proper land management in mountain regions such as the Himalayas.

The Garhwal Himalaya is one of the hotspots of biodiversity situated in the western part of the Uttarakhand Himalaya [30]. Extensive deforestation and fragmentation of the forests in the Garhwal Himalaya have caused serious environmental degradation [1,31,32], which is a critical issue in the Uttarakhand Himalaya and a basic reason for biodiversity loss [32]. According to data from the Ministry of Environment and Forests (MoEF), 44,868 hectares of forest land have been changed to non-forest use in Uttarakhand since 1980, 9500 hectares of which have been converted for the construction of roads, followed by 5500 hectares for hydro-projects and 3100 hectares for transmission lines. Agriculture is the main occupation of the people of the Garhwal Himalaya. About $70 \%$ of the population is directly and indirectly employed in the agriculture sector [33], which may lead to the overexploitation of natural resources in the region. Not surprisingly, the fragile nature of the Garhwal Himalaya coupled with increasing human activity poses a serious threat to the natural landscape, especially in the forest ecosystem. Therefore, forest cover has been under pressure over the last few decades in the region.

The present study focuses on the Rudraprayag district of the Uttarakhand state, situated in the Garhwal Himalaya region of India (Figure 1). The Rudraprayag district has been continuously experiencing extensive forest loss, due to agriculture expansion and infrastructure development. The forest in this area has been converted for hydroelectric projects (62.93 hectares), roads (187.52 hectares), or other activities (299.08 hectares) [34]. On the other hand, natural hazards such as floods, landslides, and forest fires have increased over the last few decades and have led to further deterioration of the forest landscape in the study area [10]. For example, a vegetation cover mapping was done at the National Remote Sensing Centre (NRSC) for the flood affected area of the Mandakini river between Kedarnath to Rudraprayag during the 16th and 17th of June 2013. The assessment shows that the vegetation cover had changed at 50 locations. The loss of forest cover was 46 hectares and the loss of grassland cover was 124.9 hectares in the Rudraprayag district. Recently, in 2016, a study was conducted by the Forest Department of Uttarakhand, which was related to the forest fire in Uttarakhand. According to the report, 79 locations experienced forest fires in the forest area, and the loss of forest cover was 157.20 hectares in the forest fire incident in the Rudraprayag district between April and May 2016. These are some examples that have indicated the anthropogenic pressure on natural resources and the natural vulnerability of this region.

The Rudraprayag district has experienced the extensive loss of forest in the past due to human activities and natural hazards, but data and documentation detailing this are limited. The present study is designed to fill this gap and to provide detailed information about land cover change and forest fragmentation in the study area. Satellite remote sensing and the use of geographical information systems (GIS) have emerged as powerful tools to create a spatial inventory of natural resources and play crucial roles in monitoring and analysing spatial and dynamic changes of an area [35]. Therefore, 
this study applies satellite remote sensing: (1) to analyse the spatial-temporal trends in land-use/cover change from 1976 to 2014 and (2) to evaluate forest fragmentation due to the land cover change.

\section{Materials and Methods}

\subsection{Study Area}

The study area, i.e., the Rudraprayag district, is an area of the vulnerable zone in the Garhwal Himalaya region of the Uttarakhand state in India. It extends from $30^{\circ} 12^{\prime} 58^{\prime \prime} \mathrm{N}$ to $30^{\circ} 48^{\prime} 47^{\prime \prime} \mathrm{N}$ latitude and $78^{\circ} 50^{\prime} 07^{\prime \prime} \mathrm{E}$ to $79^{\circ} 22^{\prime} 34^{\prime \prime} \mathrm{E}$ longitude. The geographical area of the Rudraprayag district is around $1936.06 \mathrm{~km}^{2}$ (Figure 1). As per the report of the Disaster Mitigation and Management Centre (DMMC), the Rudraprayag district is a land of deep valleys, high ridges, and steep mountains. It is comprised of two main tectonic units, viz. the Garhwal group and Central Crystalline group, and covers two sections of the Himalaya: the Lesser Himalaya and Greater Himalaya [36,37]. In the study area, rainfall is highly variable depending upon the altitude. In the southern part of the district at Rudraprayag, the average annual rainfall is around $1220 \mathrm{~mm}$, while in the central part at Chandrapuri, the average annual rainfall is $1751 \mathrm{~mm}$, and the rainfall in the northern higher part at Ukhimath is $1995 \mathrm{~mm}$ [38]. The overall average rainfall in the district is $1485 \mathrm{~mm}$. Most of the rainfall (70-80\% of annual precipitation) occurs from June to September. The mean air temperature in winter (December to February) varies from 8.32 to $13.15^{\circ} \mathrm{C}$ and from 27.75 to $32.54{ }^{\circ} \mathrm{C}$ in summer (May to July) [38]. The altitude varies from 546 to $6840 \mathrm{~m}$ above sea level (Figure 1). Mandakini is the major river of the district, with a catchment area of $1641.64 \mathrm{~km}^{2}$, and it has many tributaries. It originates from the Chorabari glacier (3895 m) (Figure 1).

The Kedarnath wildlife sanctuary has a total area of $975 \mathrm{~km}^{2}$ out of which $645 \mathrm{~km}^{2}$ is situated in the Rudraprayag district (Figure 1). It is one of the largest protected areas in Uttarakhand. Over 175 villages are located along the southern boundary of the sanctuary, whose inhabitants depend substantially on its resources for fuel wood, fodder, medicinal plants, and pastures for livestock grazing [39]. Agriculture is the primary occupation of the people. Agricultural activities are restricted on river terraces, gentle hill slopes, and intermountain valleys. The Rudraprayag district is famous for one of the most recognized pilgrim sites (Kedarnath Temple) in India. Therefore, tourism is another important livelihood option for the local people during the tourist season in the Rudraprayag district. The population of the Rudraprayag district is increasing, but, compared to the other districts of Uttarakhand, it is low. According to the 1991, 2001, and 2011 census, the Rudraprayag district had a population of 198,672 persons, 227,439 persons, and 236,857 persons, respectively, and its population growth rate over the decades of 1991-2001 and 2001-2011 was $14.4 \%$ and $4.14 \%$, respectively. According to the 2001 and 2011 census, the population density was 115 persons per $\mathrm{km}^{2}$ and 119 persons per $\mathrm{km}^{2}$, respectively. 


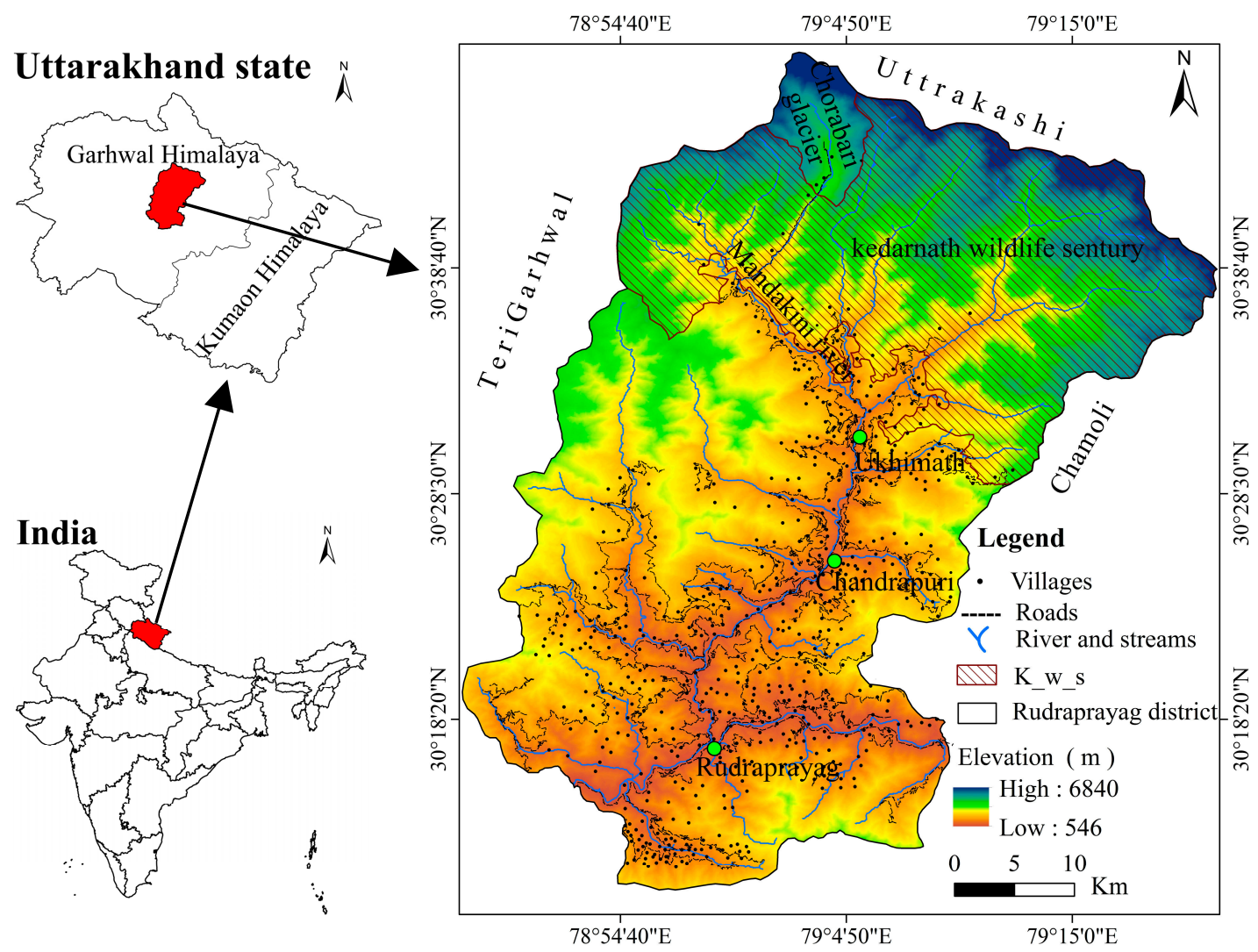

Figure 1. Location and extent of the Rudraprayag district, Uttarakhand, India.

\subsection{Data Used}

In this study, three cloud free satellite images from Landsat 2 (MSS), Landsat 5 (TM), and Landsat 8 (OLI) from the USGS (United States Geological Survey) server for land cover maps were used. These images were selected on the basis of their availability and the quality of the datasets for the study area. Table 1 summarizes the details of the satellite data used in this study.

Table 1. Details of the satellite data used in this study.

\begin{tabular}{cccccc}
\hline Satellite & Sensor & Path/Row & Spatial Resolution (M) & Date of Acquisition & Sources \\
\hline Landsat 2 & MSS & $156 / 39$ & 60 & $19 / 11 / 1976$ & USGS \\
Landsat 5 & TM & $146 / 39$ & 30 & $12 / 11 / 1998$ & USGS \\
Landsat 8 & OLI & $146 / 39$ & 30 & $24 / 11 / 2014$ & USGS \\
\hline
\end{tabular}

OLI: Operational Land Imager; USGS: United States Geological Survey. MSS: Multispectral Scanner System; TM: Thematic Mapper.

\subsection{Methods}

Figure 2 shows the overall methodological framework. Land cover maps were derived based on Landsat images for the years 1976, 1998, and 2014, using supervised classification with the maximum likelihood method. Then, land cover maps were analysed to understand the changes in land-use and land-cover, using the cross-tabulation module detection method in Arc GIS. Finally, all land cover maps were converted to forest and non-forest areas to detect forest fragmentation areas, using the landscape fragmentation tool (LFT v2.0). The details of the procedure are given in the following sections. 
Step: 1 Land cover mapping

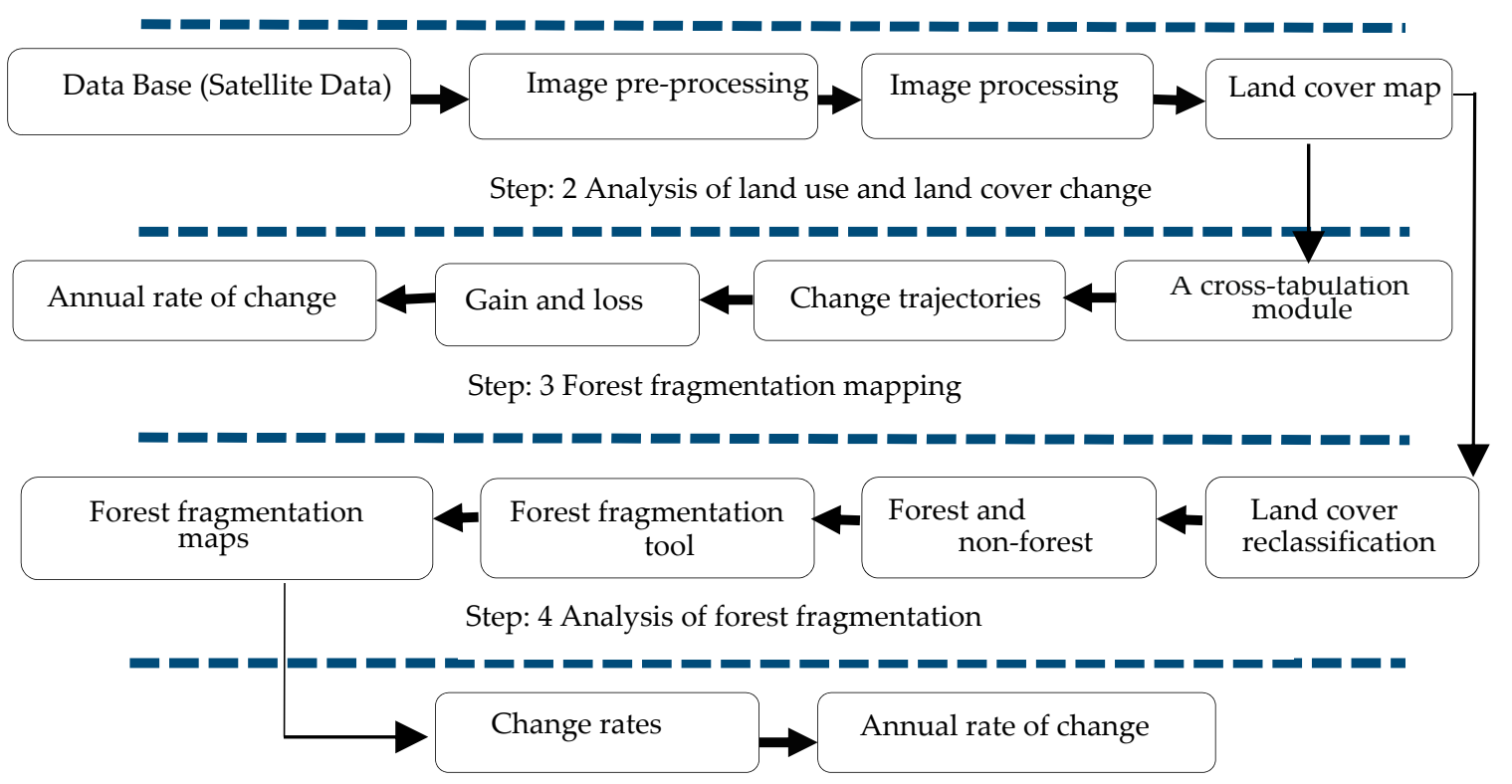

Figure 2. Overall methodological framework for the study.

\subsubsection{Land Cover Classification Scheme}

Due to the mountainous topography of the study area, image preprocessing of the satellite images was necessary to reduce or eliminate differences between the two dates due to atmospheric or sensor variations [40,41]. Therefore, the Fast Line-of-sight Atmospheric Analysis of Spectral Hypercube $\left(\right.$ FLAASH $\left.^{\circledR}\right)$ model was applied to improve radiometric and atmospheric correction in this study using the software ENVI 5.1. The FLAASH model technique was applied for handling particularly stressing atmospheric condition, such as the presence of clouds and surface reflectance. For geometric registration, the 2014 image was geo-referenced using ground control points by GPS and Google Earth. Then, the images of 1976 and 1998 were matched with the geometrically corrected OLI images from 2014 by means of an image-to-image matching method, provided by the ERDAS Imagine software. Afterwards, all images were re-sampled using the nearest neighbor technique with a root mean square error of less than \pm 0.5 pixel per image to a $30 \mathrm{~m}$ resolution with the common Universal Traverse Mercator (UTM) $44 \mathrm{~N}$ zone.

A classification scheme was developed based on ancillary information (Table 2), fieldwork, local knowledge, and visual interpretation of each class of land cover. The visual interpretation was completed using ArcGIS to obtain a training set for each class that was completed based on field observation and Google Earth. In addition, unsupervised classification and NDVI (Normalized Difference Vegetation Index) determination were also applied before the supervised classification to aid in the identification of dominant land-cover types and improve the classification accuracy. Then, supervised classifications using the maximum likelihood method were performed in ERDAS IMAGINE for the 1976, 1998, and 2014 Landsat images. For each class, 20 ground-truth polygons were digitized based on a visual analysis of the locations on Google Earth and on the image itself. To improve classification, training polygons with confusing spectral signatures were discarded, and new ones were created based on a visual analysis of the locations on Google Earth and on the image itself. Afterwards, the maximum likelihood algorithm was run again [42]. The identified nine land cover classes included dense forest, open forest, pasture land, agriculture land, built-up area, scrub land, barren land, water bodies, and snow and glacier. 
Table 2. Land-cover classification scheme.

\begin{tabular}{cc}
\hline Land Cover & Description \\
\hline $\begin{array}{c}\text { Dense forest } \\
\text { Open forest }\end{array}$ & All lands with tree canopy density of $40-70 \%$ and above \\
Scrub land & $\begin{array}{c}\text { Degraded forest lands with canopy density less than } 10 \% \\
\text { Lands not included in any of the above class such as agriculture, } \\
\text { built-up, barren, pasture, water bodies, snow / glacier }\end{array}$ \\
\hline
\end{tabular}

Source: Forest survey of India, Dehradun, India state of forest report (2011) [43].

\subsubsection{Accuracy Assessment}

Accuracy assessment is important in validating the digitally classified images. It is the procedure used to compare the classification results to the geographical reference data that are assumed to be true [44]. Due to the mountainous topography of the study area, ground reference data were collected from Google Earth with limited ground GPS points. To assess the accuracy of the classification, field visits were made to the study area with the help of local guides, located randomly below $3000 \mathrm{~m}$ elevation (as the elevations above this were not accessible due to difficult terrain), using a handheld Garmin Global Positioning System (GPS; 12-channel Garmin eTrex 30-Summit mode). The accuracy assessment of the 1976 and 1998 images were not possible due to lack of data availability and a clear Google Earth image archive. Therefore, an accuracy assessment was performed for the 2014 image only. For the 2014 image, a total of 270 ( 30 pixels from each class) testing pixels were generated at random throughout the study area. The testing pixels were compared with the classified map. To evaluate the user's and the producer's accuracy an error matrix was applied, to compare the relationship between the classified map and reference data [45]. As a result, the producer's accuracy, user's accuracy, overall accuracy, and kappa coefficient were computed for the final land cover maps produced.

\subsubsection{Land-Use and Land-Cover (LULC) Change Analysis}

A cross-tabulation module detection method was used to detect land-use and land-cover change (LULC) in ArcGIS [46], through which a LULC change matrix was produced. This matrix provides essential information about the nature and spatial distribution of land use changes [47]. A change matrix enables the main types of changes or directions in the study area. Then, the change in LULC was analysed to depict gains and losses for the two time periods. The change matrices of the 1st period (1976-1998) and the 2nd period (1998-2014) were also used to drive the gains and losses for land-cover categories. The gains for each class were derived by subtracting the persistence from the column total, and the losses were computed by subtracting the persistence from the row total.

\subsubsection{Assessment of Forest Fragmentation}

The ArcGIS Landscape Fragmentation tool (LFT v2.0) was used to create the forest fragmentation maps [48]. The input data of this tool, i.e., forest and non-forest data, were derived from the land cover maps. The land cover maps for the years 1976, 1998, and 2014 were reclassified into forest and non-forest classes using the ArcGIS spatial analyst. Scrub land was not included in the forest class (Table 2). Based on the forest and non-forest classes, the LFT v2.0 tool classifies a forest pattern into four main categories: patch, edge, perforated, and core [48]. Edge-width is the distance over which non-forest land cover can degrade forest land covers, although the edge-width varies by species and can range from $50 \mathrm{~m}$ to several $100 \mathrm{~m}$. However, $100 \mathrm{~m}$ is often used as a general edge-width [48]. Therefore, using a specified edge width of $100 \mathrm{~m}$, the forest fragmented areas were classified in five categories: (i) "core" forest-the inner part of the forest region that is relatively distant from the non-forest boundary; (ii) "patch" forest—small forest area surrounded by non-forested land cover which does not contain any core pixel forests; (iii) "perforated" forest-transition zone boundaries between the core forest and relatively small perforations; (iv) "edge" forest—-transition zone boundaries 
between the core forest and large non-forest land cover region; and (v) "non-forest" — not pertaining to forest $[48,49]$.

\subsubsection{Annual Rate of Change of LULC and Forest Fragmentation}

The annual rate of change for each class of LULC and an annual fragment creation rate were calculated using the following formula proposed by [50]:

$$
r=\left(\frac{1}{t_{2}-t_{1}}\right) \times \ln \left(\frac{A_{2}}{A_{1}}\right),
$$

where $r$ is the change for each class per year, $A_{2}$ and $A_{1}$ are the class areas at the end and the beginning, respectively, for the period being evaluated, and $t$ is the number of years spanning that period.

\section{Results}

\subsection{Land Cover Maps and Status}

The land cover maps for the years 1976, 1998, and 2014 based on Landsat 2 (MSS), Landsat 5 (TM), and Landsat 8 (OLI) satellite data were prepared with nine land-cover types, namely, dense forest, open forest, pasture land, snow and glacier, barren land, scrub land, agriculture land, water bodies, and built-up area. Figure 3 shows the final output of the supervised classification, which consists of three classified maps of the Rudraprayag district, for 1976, 1998, and 2014 and a comparison in terms of the total area for each land cover category.
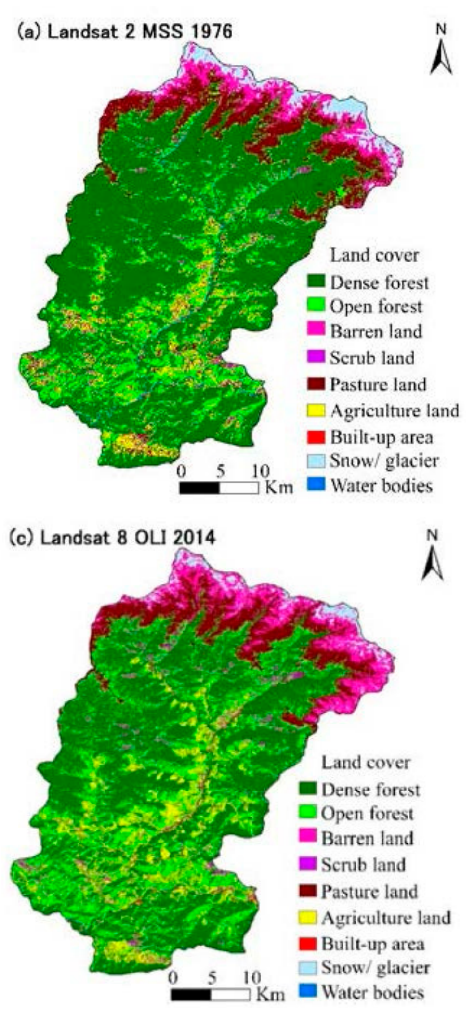

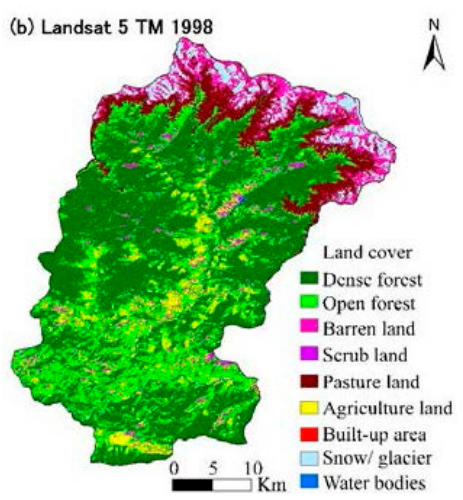

(d)

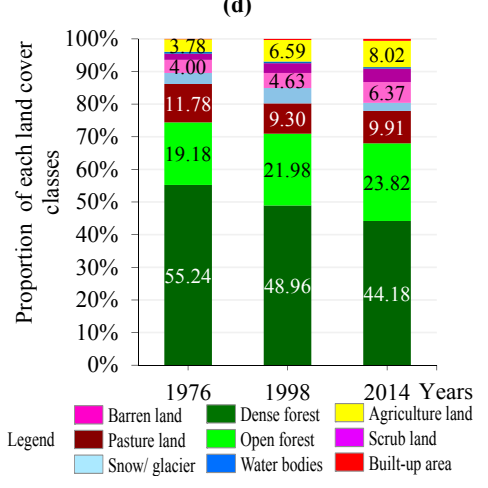

Figure 3. Land-cover map for the year (a) 1976; (b) 1998; and (c) 2014; and (d) comparison of land use and land cover classes by percentage of the total study area (study area $=936.06 \mathrm{~km}^{2}$ ).

\subsection{Accuracy Assessment}

Table 3 shows the error matrix with the user's accuracy, producer's accuracy, and kappa coefficient. The overall accuracy was calculated from the error matrix (Table 3) by dividing the correctly classified 
pixel by the total number of the pixels, i.e., $(240 / 267) \times 100=89.88 \%$. Therefore, the total accuracy was $89.88 \%$ for the 2014 classified map. Furthermore, the Kappa coefficient was calculated for the 2014 classified map at $0.8818(88.18 \%)$.

Table 3. Cross-tabulation error matrix of classified vs. reference data for 2014.

\begin{tabular}{|c|c|c|c|c|c|c|c|c|c|c|}
\hline Classified Image & \multicolumn{10}{|c|}{ Reference Data } \\
\hline Open forest & 1 & 25 & & & & & & 1 & 1 & 28 \\
\hline Pasture land & & & 26 & & 1 & 2 & & 1 & & 30 \\
\hline Snow/glacier & & & & 30 & 1 & & & & & 31 \\
\hline Water bodies & & & & & 1 & & 29 & & & 30 \\
\hline Agriculture land & 1 & 2 & 1 & & & 1 & & 26 & 3 & 34 \\
\hline Built-up area & & 1 & & & & & & 1 & 23 & 25 \\
\hline Column totals & 30 & 30 & 30 & 30 & 30 & 29 & 30 & 30 & 26 & 267 \\
\hline User's accuracy & 96.55 & 89.29 & 86.67 & 96.77 & 87.10 & 81.25 & 96.67 & 76.47 & 92.00 & \\
\hline Producer's accuracy & 93.33 & 83.33 & 86.67 & 100 & 90.00 & 89 & 96.67 & 86.67 & 82.14 & \\
\hline
\end{tabular}

\subsection{Land-Use and Land-Cover (LULC) Change}

Table 4 summarizes the results of the land cover, change rate, and annual rate of change in area of each class for the Rudraprayag district. Forest area (dense forest and open forest) was the main land cover in 1976 with $74.42 \%$ of the total area of the Rudraprayag district, followed by pasture land $(11.78 \%)$, barren land $(4.00 \%)$, agriculture land $(3.78 \%)$, and scrub land $(1.89 \%)$. The area of dense forest decreased from $55.24 \%\left(1069.51 \mathrm{~km}^{2}\right)$ in 1976 to $44.18 \%\left(855.39 \mathrm{~km}^{2}\right)$ in 2014 . On the other hand, open forest increased from $19.18 \%\left(371.3 \mathrm{~km}^{2}\right)$ in 1976 to $23.82 \%\left(461.08 \mathrm{~km}^{2}\right)$ in 2014 . The area of pasture decreased from $11.78 \%\left(227.98 \mathrm{~km}^{2}\right)$ in 1976 to $9.91 \%\left(191.78 \mathrm{~km}^{2}\right)$ in 2014 . Agriculture and built-up areas progressively increased from $3.78 \%$ and $0.14 \%$ in 1976 to $8.02 \%$ and $0.62 \%$ in 2014 , respectively. Barren and scrub land areas also progressively increased from $4.0 \%$ and $1.89 \%$ in 1976 to $6.37 \%$ and $4.12 \%$ in 2014, respectively. Due to climatic or seasonal variation, the areas under snow and glacier and water bodies decreased from $3.38 \%\left(65.5 \mathrm{~km}^{2}\right)$ and $0.61 \%\left(11.86 \mathrm{~km}^{2}\right)$ in 1976 to $2.51 \%\left(48.61 \mathrm{~km}^{2}\right)$ and $0.46 \%\left(8.94 \mathrm{~km}^{2}\right)$ in 2014 , respectively.

The overall annual rate of change in the declining phase of forest cover (dense and open forest) was observed at about $0.22 \%$ and $0.27 \%$ during the 1st period (1976-1998) and 2nd period (1998-2014), respectively. Another declining annual rate of change was observed for pasture land and snow and glacier during the 1st period (1976-1998), while water bodies and snow and glacier were observed to be in decline during the 2nd period (1998-2014). Other land cover classes experienced an expansion at both time intervals.

Table 4. Land cover area, percentage, change, and annual rate of change of the Rudraprayag district.

\begin{tabular}{|c|c|c|c|c|c|c|c|c|c|c|}
\hline \multirow{2}{*}{ Land-Cover Type } & \multicolumn{2}{|c|}{1976} & \multicolumn{2}{|c|}{1998} & \multicolumn{2}{|c|}{2014} & \multirow{2}{*}{$\begin{array}{c}\text { Change } \\
(1976-1998) \\
\% \text { b }\end{array}$} & \multirow{2}{*}{$\begin{array}{c}\text { Change } \\
(1998-2014) \\
\% \mathrm{~b}\end{array}$} & \multirow{2}{*}{$\begin{array}{c}\text { Annual Rate of } \\
\text { Change (1976-1998) } \\
\%^{c}\end{array}$} & \multirow{2}{*}{$\begin{array}{c}\text { Annual Rate of } \\
\text { Change (1998-2014) } \\
\%^{c}\end{array}$} \\
\hline & $\mathrm{km}^{2}$ & $\%^{a}$ & $\mathrm{~km}^{2}$ & $\%^{a}$ & $\mathrm{~km}^{2}$ & $\%^{a}$ & & & & \\
\hline Dense forest & 1069.51 & 55.24 & 947.96 & 48.96 & 855.39 & 44.18 & -6.27 & -4.78 & -0.55 & -0.64 \\
\hline Open forest & 371.3 & 19.18 & 425.53 & 21.98 & 461.08 & 23.82 & 2.80 & 1.83 & 0.62 & 0.50 \\
\hline Pasture land & 227.98 & 11.78 & 180.1 & 9.30 & 191.78 & 9.91 & -2.47 & 0.60 & -1.07 & 0.39 \\
\hline Snow/glacier & 65.5 & 3.38 & 91.09 & 4.70 & 48.61 & 2.51 & 1.32 & -2.19 & 1.50 & -3.93 \\
\hline Barren land & 77.37 & 4.00 & 89.58 & 4.63 & 123.33 & 6.37 & 0.63 & 1.74 & 0.67 & 2.00 \\
\hline Scrub land & 36.54 & 1.89 & 57.31 & 2.96 & 79.70 & 4.12 & 1.07 & 1.15 & 2.05 & 2.06 \\
\hline Water bodies & 11.86 & 0.61 & 10.45 & 0.54 & 8.94 & 0.46 & -0.07 & -0.08 & -0.58 & -0.98 \\
\hline Agriculture land & 73.22 & 3.78 & 127.51 & 6.59 & 155.34 & 8.02 & 2.80 & 1.44 & 2.52 & 1.23 \\
\hline Built-up area & 2.78 & 0.14 & 6.53 & 0.34 & 11.91 & 0.62 & 0.19 & 0.28 & 3.88 & 3.75 \\
\hline Total area & 1936.06 & 100.00 & 1936.06 & 100.00 & 1936.06 & 100.00 & & & & \\
\hline
\end{tabular}




\subsection{Land-Use and Land-Cover (LULC) Change Trajectories}

Tables 5 and 6 show the conversion of the land cover in the form of a change matrix for the 1st period (1976-1998) and 2nd period (1998-2014). In the 1st period (1976-1998), there was a major conversion from forest cover (dense and open forest) to agriculture land $\left(44.79 \mathrm{~km}^{2}\right)$, from forest to scrub land $\left(25.33 \mathrm{~km}^{2}\right)$, from forest to barren land $\left(5.86 \mathrm{~km}^{2}\right)$, and from forest to built-up area $\left(2.18 \mathrm{~km}^{2}\right)$. In the same period, a change from snow and glacier to barren land, from pasture to agriculture land, and from barren land to snow and glacier were also observed. On the other hand, the 2nd period (1998-2014) showed a further major loss of forest cover (dense and open forest), being converted to agriculture land $\left(39.8 \mathrm{~km}^{2}\right)$, scrub land $\left(29.95 \mathrm{~km}^{2}\right)$, built-up area $\left(4.13 \mathrm{~km}^{2}\right)$, barren land $\left(3.51 \mathrm{~km}^{2}\right)$, and pasture land $\left(5.13 \mathrm{~km}^{2}\right)$. During the same time period, another major change from snow and glacier to barren land was also observed. A few areas were converted to forest in the study area during both periods.

Table 5. Land-Use and Land-Cover (LULC) change matrix between 1976 and 1998.

\begin{tabular}{lcccccccccc}
\hline $\begin{array}{c}\text { Land-Cover } \\
\text { Type } \mathbf{( k m}^{\mathbf{2}} \mathbf{n}\end{array}$ & $\begin{array}{c}\text { Dense } \\
\text { Forest }\end{array}$ & $\begin{array}{c}\text { Open } \\
\text { Forest }\end{array}$ & $\begin{array}{c}\text { Pasture } \\
\text { Land }\end{array}$ & Snow/Glacier & $\begin{array}{c}\text { Barren } \\
\text { Land }\end{array}$ & $\begin{array}{c}\text { Scrub } \\
\text { Land }\end{array}$ & $\begin{array}{c}\text { Water } \\
\text { Bodies }\end{array}$ & $\begin{array}{c}\text { Agriculture } \\
\text { Land }\end{array}$ & $\begin{array}{c}\text { Built-up } \\
\text { Area }\end{array}$ & $\begin{array}{c}\text { Total } \\
(\mathbf{1 9 9 8 )}\end{array}$ \\
\hline Dense forest & $\mathbf{9 2 8 . 2 6}$ & 13.35 & 0.73 & 0 & 0.08 & 1.71 & 0 & 3.83 & 0 & 948.00 \\
Open forest & 130.43 & $\mathbf{2 8 4 . 7}$ & 1.62 & 0 & 0.4 & 3.09 & 0 & 5.28 & 0 & 425.50 \\
Pasture land & 0.48 & 4.85 & $\mathbf{1 5 0 . 0 7}$ & 0 & 19.61 & 2.45 & 0.18 & 2.46 & 0 & 180.10 \\
Snow /glacier & 0.02 & 0.55 & 32.85 & $\mathbf{3 8 . 8 4}$ & 18.83 & 0 & 0 & 0 & 0 & 91.09 \\
Barren land & 0.42 & 5.44 & 16.9 & 26.16 & $\mathbf{3 6 . 9 4}$ & 1.07 & 2.23 & 0.42 & 0 & 89.58 \\
Scrub land & 3.54 & 21.79 & 2.06 & 0 & 0.27 & $\mathbf{2 1 . 4 1}$ & 0 & 8.24 & 0 & 57.31 \\
Water bodies & 0 & 0 & 0 & 0.5 & 0.92 & 0 & $\mathbf{8 . 9 3}$ & 0.1 & 0 & 10.45 \\
Agriculture land & 6.01 & 38.78 & 23.56 & 0 & 0.32 & 6.64 & 0.45 & $\mathbf{5 1 . 7 5}$ & 0 & 127.50 \\
Built-up area & 0.35 & 1.83 & 0.19 & 0 & 0 & 0.17 & 0.07 & 1.14 & $\mathbf{2 . 7 8}$ & 6.53 \\
Total (1976) & 1069.51 & 371.00 & 227.98 & 65.50 & 77.37 & 36.50 & 11.86 & 73.22 & 2.78 & 1936.06 \\
\hline
\end{tabular}

Note: The bold letters indicate that there is no change in the LULC over the time period.

Table 6. Land-Use and Land-Cover (LULC) change matrix between 1998 and 2014.

\begin{tabular}{lcccccccccc}
\hline $\begin{array}{c}\text { Land-Cover } \\
\left.\text { Type } \mathbf{( k m}^{2}\right)\end{array}$ & $\begin{array}{c}\text { Dense } \\
\text { Forest }\end{array}$ & $\begin{array}{c}\text { Open } \\
\text { Forest }\end{array}$ & $\begin{array}{c}\text { Pasture } \\
\text { Land }\end{array}$ & Snow/Glacier & $\begin{array}{c}\text { Barren } \\
\text { Land }\end{array}$ & $\begin{array}{c}\text { Scrub } \\
\text { Land }\end{array}$ & $\begin{array}{c}\text { Water } \\
\text { Bodies }\end{array}$ & $\begin{array}{c}\text { Agriculture } \\
\text { land }\end{array}$ & $\begin{array}{c}\text { Built-up } \\
\text { Area }\end{array}$ & $\begin{array}{c}\text { Total } \\
(\mathbf{2 0 1 4})\end{array}$ \\
\hline Dense forest & $\mathbf{8 3 2 . 3}$ & 17.69 & 0.52 & 0 & 0.35 & 0.36 & 0 & 4.21 & 0 & 855.40 \\
Open forest & 104.9 & $\mathbf{3 3 6 . 1}$ & 1.15 & 0 & 2.16 & 8.33 & 0 & 8.42 & 0 & 461.10 \\
Pasture land & 0.82 & 4.31 & $\mathbf{1 5 7}$ & 0 & 23.6 & 2.72 & 0.39 & 3.32 & 0 & 191.8 \\
Snow /glacier & 0 & 0 & 0.93 & $\mathbf{3 8 . 8 4}$ & 8.85 & 0 & 0 & 0 & 0 & 48.61 \\
Barren land & 0.5 & 3.01 & 11.2 & 52 & $\mathbf{5 3 . 8}$ & 0.62 & 1.68 & 0.41 & 0.12 & 123.30 \\
Scrub land & 3.95 & 26 & 3.78 & 0.03 & 0.03 & $\mathbf{4 1 . 2}$ & 0 & 4.73 & 0 & 79.70 \\
Water bodies & 0 & 0 & 0 & 0.19 & 0.49 & 0.21 & $\mathbf{7 . 3 5}$ & 0.2 & 0.49 & 8.93 \\
Agriculture land & 4.63 & 35.17 & 5.75 & 0 & 0.32 & 3.7 & 0.82 & $\mathbf{1 0 4 . 4 2}$ & 0.53 & 155.30 \\
Built-up area & 0.92 & 3.21 & 0.18 & 0 & 0 & 0.19 & 0.21 & 1.8 & 5.39 & 11.90 \\
Total (1998) & 948.00 & 425.50 & 180.10 & 91.09 & 90 & 57.31 & 10.45 & 127.50 & 6.53 & 1936.06 \\
\hline
\end{tabular}

Note: The bold letters indicate that there is no change in the LULC over the time period.

\subsection{Gain and Loss of Land-Use and Land-Cover (LULC)}

The net change in the form of gains and losses for each class during the 1st period (1976-1998) and the 2nd period (1998-2014) is shown in Figure 4. The highest loss was in the dense forest $\left(121.55 \mathrm{~km}^{2}\right)$ during the 1st period, followed by pasture land $\left(47.88 \mathrm{~km}^{2}\right)$, and water bodies $\left(1.94 \mathrm{~km}^{2}\right)$, while a significant gain was observed in agriculture land $\left(54.29 \mathrm{~km}^{2}\right)$, open forest $\left(54.23 \mathrm{~km}^{2}\right)$, snow and glacier $\left(25.59 \mathrm{~km}^{2}\right)$, scrub land $\left(20.77 \mathrm{~km}^{2}\right)$, barren land $\left(12.21 \mathrm{~km}^{2}\right)$, built-up area $\left(3.75 \mathrm{~km}^{2}\right)$, and water bodies $\left(1.41 \mathrm{~km}^{2}\right)$. An overall loss of $67.32 \mathrm{~km}^{2}$ of forest area (dense and open forest) was observed during the 1st period. On the other hand, the highest loss was observed in dense forest $\left(92.57 \mathrm{~km}^{2}\right)$ and snow and glacier $\left(42.48 \mathrm{~km}^{2}\right)$, while significant gains were observed in open forest $\left(35.55 \mathrm{~km}^{2}\right)$, barren land $\left(33.75 \mathrm{~km}^{2}\right)$, agriculture land $\left(27.83 \mathrm{~km}^{2}\right)$, scrub land $\left(22.39 \mathrm{~km}^{2}\right)$, pasture land $\left(11.68 \mathrm{~km}^{2}\right)$, and built-up area $\left(5.37 \mathrm{~km}^{2}\right)$ during the 2 nd period. An overall loss of $57.03 \mathrm{~km}^{2}$ of forest area (dense and open forest) was observed during the 2 nd period. However, the overall net change was the highest during the 1st period. 


\begin{tabular}{|l|l|l|l|}
\hline & & & \\
\hline
\end{tabular}

Figure 4. Net change (i.e., gains minus losses) for each land cover class of the study area for the 1st period (1976-1998) and the 2nd period (1998-2014).

\subsection{Forest Fragmentation Pattern and Status}

The forest fragmentation pattern maps for the years 1976, 1998, and 2014 based on forest and non-forest areas were generated by using LFT v2.0. Forest fragmentation maps with categories such as patch, edge, perforated, small core, medium core, and large core are shown in Figure 5.
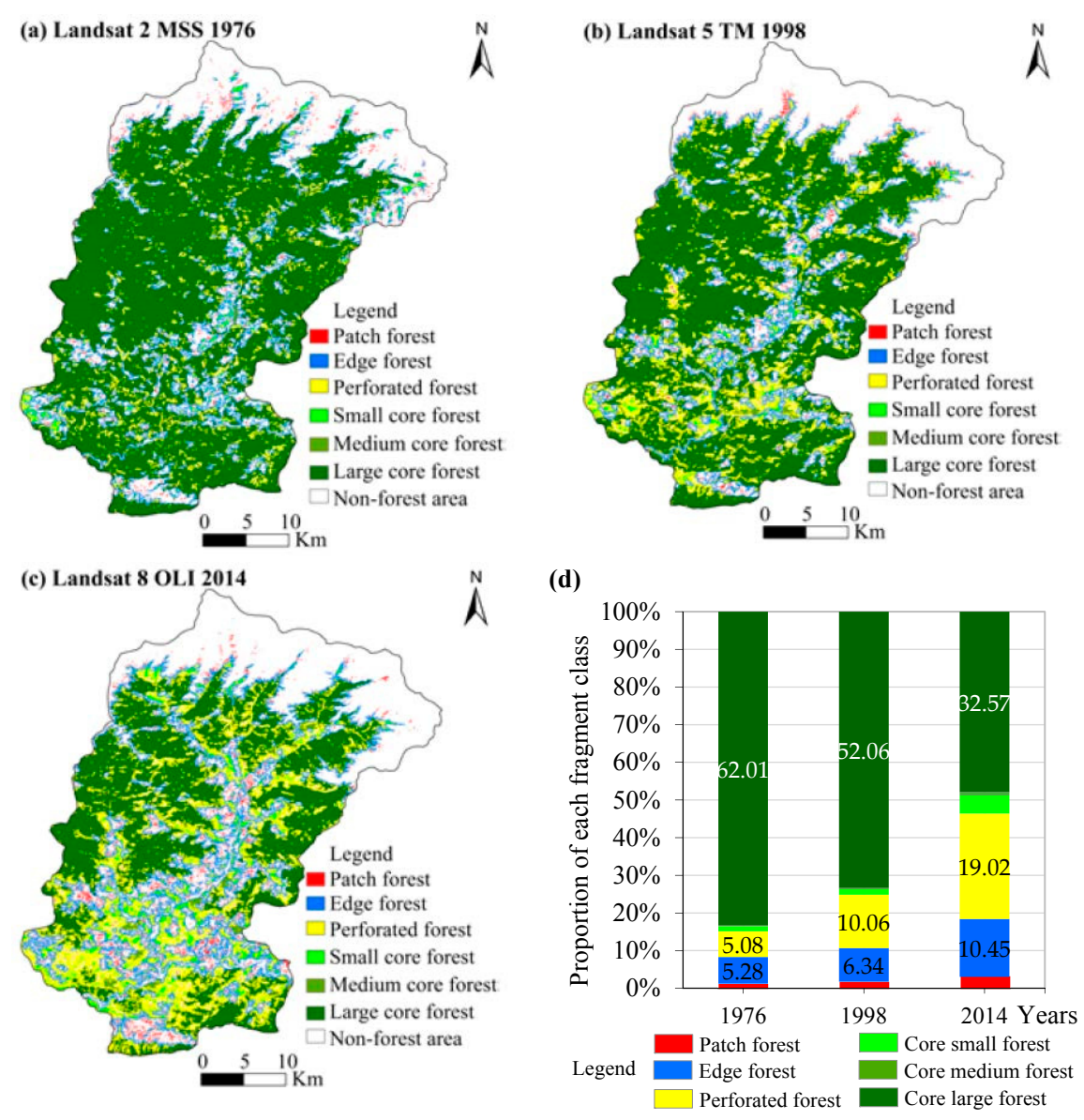

Figure 5. Maps of the forest fragmentation pattern in the Rudraprayag district for the years (a) 1976; (b) 1998; and (c) 2014; and (d) a comparison of the forest fragment pattern classes by percentage of the total study area (study area $=1936.06 \mathrm{~km}^{2}$ ). 


\subsection{Forest Fragmentation Change}

Table 7 summarizes the forest fragmentation change from 1976 to 2014. Forest fragmentation analysis shows a significant decrease in the compact forest area (large core forest) from 1976 to 2014. In 1976, the large core forest was dominant covering $62.01 \%$ of the total study area, followed by edge forest $(5.28 \%)$, perforated forest $(5.08 \%)$, small core $(1.03 \%)$, patch forest $(0.90 \%)$, and medium core $(0.12 \%)$. Between 1998 and 2014, the large core forest decreased, while medium core, small core, edge, and patch forest continuously increased.

The area of large core forest decreased from $62.01 \%$ in 1976 to $32.57 \%$ in 2014, showing a component change of $9.95 \%$ and $19.49 \%$ in the 1st period (1976-1998) and the 2nd period (1998-2014), respectively. The area under patch, edge, perforated, and medium core forest progressively increased from $0.90 \%, 5.28 \%, 5.08 \%$, and $0.12 \%$ in 1976 to $2.07 \%, 10.45 \%, 19.02 \%$, and $0.61 \%$ in 2014 , respectively, showing a component change of $0.34 \%, 1.32 \%, 4.97 \%$, and $0.10 \%$ in the 1 st period and $0.83 \%, 4.01 \%$, $8.96 \%$, and $0.38 \%$ in the 2 nd period, respectively. Small core forest slightly decreased by $1.02 \%$ in 1998 , and then drastically increased by $3.28 \%$ in 2014 , showing a decreased change of $0.01 \%$ in the 1 st period and an increased change of $2.25 \%$ in the 2 nd period. An overall decrease in forest area from $3.47 \%$ in the 1 st period to $2.94 \%$ in the 2 nd period was observed, while an overall increase in non-forest area from $3.47 \%$ in the 1 st period to $2.94 \%$ in the 2 nd period was observed.

A declining annual rate of change for large core forest was observed at about $0.79 \%$ and $2.93 \%$ in the 1st period (1976-1998) and the 2nd period (1998-2014), respectively. Other increasing annual rates of change were observed in patch, edge, perforated, and medium core forests in the 1st period and the 2nd period, although small core forest decreased in the 1st period, and then increased again in the 2 nd period. A declining overall annual rate of change for the total forest cover was observed at $0.22 \%$ and $0.27 \%$ for the 1 st period and the 2 nd period, respectively. As a result, the overall annual rate of change in non-forest increased from $0.58 \%$ in the 1 st period to $0.60 \%$ in the 2 nd period.

Table 7. Forest fragmentation in area, percentage, and annual rate of change of each class.

\begin{tabular}{|c|c|c|c|c|c|c|c|c|c|c|}
\hline \multirow{2}{*}{$\begin{array}{l}\text { Fragmentation } \\
\text { Classes }\end{array}$} & \multicolumn{2}{|c|}{1976} & \multicolumn{2}{|c|}{1998} & \multicolumn{2}{|c|}{2014} & \multirow{2}{*}{$\begin{array}{c}\begin{array}{c}\text { Change } \\
(1976-1998)\end{array} \\
\%^{b}\end{array}$} & \multirow{2}{*}{$\begin{array}{c}\begin{array}{c}\text { Change } \\
(1998-2014)\end{array} \\
\%^{b}\end{array}$} & \multirow{2}{*}{$\begin{array}{c}\begin{array}{c}\text { Annual Rate of } \\
\text { Change (1976-1998) }\end{array} \\
\%^{c}\end{array}$} & \multirow{2}{*}{$\begin{array}{c}\begin{array}{c}\text { Annual Rate of } \\
\text { Change (1998-2014) }\end{array} \\
\%^{c}\end{array}$} \\
\hline & $\mathrm{km}^{2}$ & $\%^{a}$ & $\mathrm{~km}^{2}$ & $\%^{a}$ & $\mathrm{~km}^{2}$ & $\%^{a}$ & & & & \\
\hline Patch & 17.46 & 0.90 & 23.97 & 1.24 & 40.13 & 2.07 & 0.34 & 0.83 & 1.44 & 3.22 \\
\hline Perforated & 98.32 & 5.08 & 194.69 & 10.06 & 368.32 & 19.02 & 4.97 & 8.96 & 3.11 & 3.98 \\
\hline Small core & 19.91 & 1.03 & 19.74 & 1.02 & 63.41 & 3.28 & -0.01 & 2.25 & -0.04 & 7.29 \\
\hline Medium core & 2.39 & 0.12 & 4.37 & 0.23 & 11.76 & 0.61 & 0.10 & 0.38 & 2.73 & 6.17 \\
\hline
\end{tabular}

${ }^{a}$ Percentage of each class out of the total study area (study area $=1936.06 \mathrm{~km}^{2}$ ); ${ }^{\mathrm{b}}$ Percentage change in the component; ${ }^{\mathrm{c}}$ Percentage of the annual rate of change in each class.

\section{Discussion}

\subsection{Land-Use and Land-Cover (LULC) Change}

The results show that significant change in land cover occurred in the Rudraprayag district between 1976 and 2014. The forest was the main land cover in the study area. The overall trend shows that the forest area had decreased and the non-forest area had increased in the Rudraprayag district; the overall loss of the forest was $122.35 \mathrm{~km}^{2}$ from 1976 to 2014.This result agrees with other studies conducted in the Himalayan region of India [51,52]. The general trends of change showed an increase in agriculture, barren land, built-up area, and scrub land. The local community depends highly on agricultural activity, which would be further expected with a decline in forest cover. Other studies also found similar causes of forest decline in the Hindu Kush Himalaya (HKH) region [49,52-54]. Although natural drivers could also play a role in land cover change, the scope of this study mainly focused on anthropogenic activities. However, the loss of forest cover is particularly serious in mountain regions such as the Himalayas, where the landscape has a complex and fragile environment with 
rough terrain, unique topography, and vulnerability to numerous types of natural hazards. Therefore, the impact of natural drivers such as hazards on LULC changes could be further analysed for a more in-depth understanding.

The results displayed in Figure 3 clearly show that the majority of the agricultural activities and built-up areas are distributed along the roads and river channels at lower and middle altitudes. The significant increase in agricultural land and built-up areas contributed to the modification of the forest cover, which indicates the possibility of decrease in the forest cover in the near future. The continuous increase in the area of barren and scrub land contributed to wasteland land or non-forest land in the study area, which could lead to a huge loss in topsoil and further affect the health of the nearby forests. Significant changes in barren land at higher altitudes may also further contribute to an increase in mass movement and soil erosion $[13,54,55]$ during the heavy rainfall season in the Rudraprayag district. A drastic increase in barren land at higher altitudes might also be converted to large run-off during the rainfall season in the steep and narrow channels of the Mandakini valley, which indicates the possibility of increased flood activity in the downstream area [38]. A continued increase in scrub land indicates that the forest land is degraded at a significant rate. Some of the forest, pasture, agriculture, and built-up areas was lost during the heavy flood disaster that took place on the 16th and 17th of June 2013 [10]. The area under water bodies and snow/glaciers also showed a decreasing trend. This could be due to the climatic or seasonal variation (temporal cover of snow) over the time period.

\subsection{Forest Fragmentation}

Forest fragmentation increased because the large core forest was diminished at a significant rate. A continued decrease in the large core forest and an increase in the perforated forest indicates an increase in forest fragmentation. The increase of patch, small core, and medium core forests is indicative of the continuing disconnect of the forest from the large core forest area. The patch forest increased throughout the study period, completely degraded by the edge effect [48]. The result showed that significant change had occurred in the large core forest due to expansion of the non-forest area. The conversion of vegetation cover to non-forest area by human activity increased forest fragmentation, posing a great threat to biodiversity [32], although the increase in forest fragmentation is related to both natural and anthropogenic drivers [56]. The result of this study suggests that expansion in agricultural and built-up areas is the major driver for forest fragmentation, where topography has played a significant role in the study area. At the same time the study area is highly vulnerable to natural hazards such as heavy floods, landslides, and forest fires. It is also vulnerable to modification of the forest cover and further increase in forest fragmentation, which would further deteriorate the overall forest landscape. Fragmentation and the loss of forest due to the conversion to agriculture and other land use indicate that the available habitat is shrinking [57]. Therefore, the overall changes in forest fragmentation are likely to have a negative impact on the continuity and quantity of the forest land area [58]. The trends of forest fragmentation together with the land cover change have serious impacts on biodiversity, habitat loss, and ecosystem services in this region. Moreover, the pattern of forest fragmentation may vary at a different scale and depend on the spatial scale or resolution of the landscape.

In addition, the upper part of the study area is a protected area classified as a wildlife sanctuary. However, due to the disturbance of continuous human activities such as road development, the upward movement of people to higher elevations for agricultural activity, hydro power projects, and the increase of the built-up area within the sanctuary, the wildlife sanctuary is seriously threatened, which may change the continuity, quantity, and connectivity of the sanctuary and reduce the forest land area as a whole. 


\section{Conclusions}

This study assessed changes in land-use/land-cover and forest fragmentation in the Rudraprayag district, Garhwal Himalaya, India. The study area experienced a decrease in forest cover and an increase in agricultural land, barren land, scrub land, and built-up area between 1976 and 2014. Forest cover is likely to decrease further due to commercial exploitation, expansion of agricultural land, and human settlements. The results of the forest fragmentation analysis showed that the increase in the non-forest and perforated areas is the main cause of the decline of the large core forest. The study indicates that expansion in agriculture and the built-up area are the major drivers of forest cover change and fragmentation. The study results also suggested that forest fragmentation coupled with land cover changes may lead to forest degradation with implications for biodiversity, habitat ecosystem services, and people's livelihoods.

This study contributes to the understanding of the pattern of forest fragmentation and influence on the forest fragmentation pattern caused by land cover changes. Finding the areas where changes have occurred will help to fill the gap necessary to lead to prioritization in forest management, conservation, and biodiversity policies. This study will also fill an information gap regarding area classification, which has been heretofore poorly researched with poor data availability and will improve information at the regional and national level. Moreover, improved understanding of the drivers can help reveal the dynamics of LULC change and the forest fragmentation process of the Himalaya region at different scales.

Acknowledgments: A part of this study was supported by the Grant-in-Aid for Scientific Research, by the Japan Society for the Promotion of Science (Grant No. 16H 05641).

Author Contributions: Amit Kumar Batar performed the field survey and analyzed the data; Amit Kumar Batar and Teiji Watanabe wrote the paper; and Ajay Kumar helped with data collection during the field work.

Conflicts of Interest: The authors declare no conflict of interest. The founding sponsors had no role in the design of the study; in the collection, analyses, or interpretation of data; in the writing of the manuscript, and in the decision to publish the results.

\section{References}

1. Ives, J.D.; Messerli, B. The Himalayan Dilemma: Reconciling Development and Conservation; United Nations University: Tokyo, Japan; Routledge: Landon, UK, 1990; Volume 7.

2. Lambin, E.F.; Turner, B.L.; Geist, H.J.; Agbola, S.B.; Angelsen, A.; Folke, C.; Bruce, J.W.; Coomes, O.T.; Dirzo, R.; George, P.S.; et al. The causes of land-use and land-cover change: Moving beyond the myths. Globak Environ. Chang. 2001, 11, 261-269. [CrossRef]

3. Miehe, G.; Miehe, S.; Schlütz, F. Early human impact in the forest ecotone of southern High Asia (Hindu Kush, Himalaya). Quat. Res. 2009, 71, 255-265. [CrossRef]

4. Macchi, M.; ICIMOD. Mountains of the World-Ecosystem Services in a Time of Global and Climate Change; ICINOD Team: Kathmandu, Nepal, 2010.

5. Shrestha, U.B.; Gautam, S.; Bawa, K.S. Widespread climate change in the Himalayas and associated changes in local ecosystems. PLoS ONE 2012, 7, 1-10. [CrossRef] [PubMed]

6. Joshi, P.K.; Rawat, A.; Narula, S.; Sinha, V. Assessing impact of climate change on forest cover type shifts in Western Himalayan Eco-region. J. For. Res. 2012, 23, 75-80. [CrossRef]

7. Singh, S.P.; Singh, J.S. Analytical conceptual plan to reforest central Himalaya for sustainable development. Environ. Manag. 1991, 15, 369-379. [CrossRef]

8. Tiwari, P. Land use changes in Himalaya and their impacts on environment, society and economy: A study of the Lake Region in Kumaon Himalaya, India. Adv. Atmos. Sci. 2008, 25, 1029-1042. [CrossRef]

9. Meyer, W.B.; Turner, B.L. Human Population Growth and Global Land-Use/Cover Change. Annu. Rev. Ecol. Syst. 1992, 23, 39-61. [CrossRef]

10. Gupta, A.K.; Dobhal, D.P.; Mehta, M.; Verma, A.; Pratap, B.; Kesarwani, K. Kedarnath Devastation; Wadia Institute of Himalayan Geology: Dehradun, India, 2013. 
11. Lasch, P.; Lindner, M.; Erhard, M.; Suckow, F.; Wenzel, A. Regional impact assessment on forest structure and functions under climate change-The Brandenburg case study. For. Ecol. Manag. 2002, 162, 73-86. [CrossRef]

12. Jasrotia, A.S.; Singh, R. Modeling runoff and soil erosion in a catchment area using the GIS in the Himalayan region, India. Environ. Geol. 2006, 51, 29-37. [CrossRef]

13. Yu, H.; Joshi, P.K.; Das, K.K.; Chauniyal, D.D.; Melick, D.R.; Yang, X. Land use/cover change and environmental vulnerability analysis in Birahi Ganga sub-watershed of the Garhwal Himalaya, India. Trop. Ecol. 2007, 48, 241-250.

14. Collingham, Y.C.; Huntley, B. Impacts of Habitat Fragmentation and Patch Size upon Migration Rates. Ecol. Appl. 2013, 10, 131-144. [CrossRef]

15. Fahrig, L. Effects of habitat fragmentation on biodiversity. Annu. Rev. Ecol. Evol. Syst. 2003, 34, 487-515. [CrossRef]

16. Lambin, E.F.; Geist, H.J.; Lepers, E. Dynamics of Land-Use and Land-Cover Change in Tropical Regions. Annu. Rev. Environ. Resour. 2003, 28, 205-241. [CrossRef]

17. Foley, J.A. Global Consequences of Land Use. Science 2005, 309, 570-574. [CrossRef] [PubMed]

18. Fischer, J.; Lindenmayer, D.B. Landscape modification and habitat fragmentation: A sunthesis. Glob. Ecol. Biogeogr. 2007, 16, 265-280. [CrossRef]

19. Lele, N.; Joshi, P.K. Analyzing deforestation rates, spatial forest cover changes and identifying critical areas of forest cover changes in North-East India during 1972-1999. Environ. Monit. Assess. 2009, 1999, 159-170. [CrossRef] [PubMed]

20. Biswas, S.; Khan, D.K. Habitat Fragmentation and Nutrient Dynamics in Tropical Dry Deciduous Forests of West Bengal, India. ARPN J. Sci. Technol. 2013, 3, 109-119.

21. Leal, I.R.; Filgueiras, B.K.C.; Gomes, J.P.; Iannuzzi, L.; Andersen, A.N. Effects of habitat fragmentation on ant richness and functional composition in Brazilian Atlantic forest. Biodivers. Conserv. 2012, 21, 1687-1701. [CrossRef]

22. Sundriyal, R.C.; Sharma, E. Anthropogenic pressure on tree structure and biomass in the temperate forest of Mamlay watershed in Sikkim. For. Ecol. Manag. 1996, 81, 113-134. [CrossRef]

23. Chettri, N.; Sharma, E.; Deb, D.C.; Sundriyal, R.C. Impact of Firewood Extraction on Tree Structure, Regeneration and Woody Biomass Productivity in a Trekking Corridor of the Sikkim Himalaya. Mt. Res. Dev. 2002, 22, 150-158. [CrossRef]

24. Bawa, K.S.; Joseph, G.; Setty, S. Poverty, biodiversity and institutions in forest-agriculture ecotones in the Western Ghats and Eastern Himalaya ranges of India. Agric. Ecosyst. Environ. 2007, 121, 287-295. [CrossRef]

25. Khan, S.M.; Page, S.; Ahmad, H.; Harper, D. Anthropogenic influences on the natural ecosystem of the naran valley in the western Himalayas. Pakistan J. Bot. 2012, 44, 231-238.

26. Tiwari, P.C.; Joshi, B. Environmental Changes and their Impact on Rural Water, Food, Livelihood, and Health Security in Kumaon Himalayas. J. Urban Reg. Stud. Contemp. India. 2014, 1, 1-12.

27. Adnan, M.; Tariq, A.; Shinwari, Z.K. Effects of human proximity and nomadic grazing on the diversity of medicinal plants in temperate Hindu-kush. Pakistan J. Bot. 2015, 47, 149-157.

28. Kala, C.P. Forest structure and anthropogenic pressures in the Pachmarhi biosphere reserve of India. J. For. Res. 2015, 26, 867-874. [CrossRef]

29. Huebner, C.D.; Randolph, J.C. Environmental Factors Affecting Understory Diversity in Second-growth Deciduous Forests. Am. Midl. Nat. 1995, 134, 155-165. [CrossRef]

30. Chandra, J.; Rawat, V.S.; Rawat, Y.S.; Ram, J. Vegetational diversity along an altitudinal range in Garhwal Himalaya. Int. J. Biodivers. Conserv. 2010, 2, 14-18.

31. Roy, P.S.; Tomar, S. Biodiversity characterization at landscape level using geospatial modelling technique. Biol. Conserv. 2000, 95, 95-109. [CrossRef]

32. Sharma, S.; Roy, P.S. Forest fragmentation in the Himalaya: A Central Himalayan case study. Int. J. Sustain. Dev. World Ecol. 2007, 14, 201-210. [CrossRef]

33. Sati, V.P. Agricultural Diversification in the Garhwal Himalaya: A Spatio-Temporal Analysis. Sustain. Agric. Res. 2012, 1, 77-86. [CrossRef]

34. Shrivastava, k.S. Maximum devastation occurred in areas of maximum forestland diversion. Available online: http://www.downtoearth.org.in/news/maximum-devastation-occurred-in-areas-ofmaximum-forestland-diversion-41483 (accessed on 10 Feburary 2017). 
35. Mondal, S.; Sharma, N.; Kappas, M.; Garg, P.K. Critical Assessment of Land Use Land Cover Dynamics Using Multi-Temporal Satellite Images. Environments 2015, 2, 61-90. [CrossRef]

36. Kumar, G.; Agrawal, N.C. Geology of the Srinagar-Nandprayag Area (Alakananda Valley), Chamoli, Garhwal and Tehri Garhwal Districts, Kumaun Himalaya, Uttar Pradesh. Himal. Geol. 1975, 5, 29-59.

37. Kumar, G. Geology of Uttar Pradesh and Uttaranchal; Geological Society of India: Bangalore, India, 2005.

38. Rautela, P.; Sajwan, K.S.; Khanduri, S.; Ghildiyal, S.; Rawat, C.; Rawat, A. Geological Investigations in Rudraprayag District with Special Reference to Mass Instability; Disaster Mitigation and Management Centre (DMMC): Dehradun, India, 2014.

39. Kittur, S.; Sathyakumar, S. Assessment of spatial and habitat use overlap between Himalayan tahr and livestock in Kedarnath Wildlife Sanctuary, India. Eur. J. Wildl. Res. 2010, 56, 195-204. [CrossRef]

40. Jensen, J.R. Introductory Digital Image Processing: A Remote Sensing Perspective, 2nd ed.; Prentice Hall PTR: Upper Saddle River, NJ, USA, 1996.

41. Paolini, L.; Grings, F.; Sobrino, J.A.; Jiménez Muñoz, J.C.; Karszenbaum, H. Radiometric correction effects in Landsat multi-date/multi-sensor change detection studies. Int. J. Remote Sens. 2006, 27, 685-704. [CrossRef]

42. Fonji, S.F.; Taff, G.N. Using satellite data to monitor land-use land-cover change in North-eastern Latvia. Springerplus 2014, 3, 61. [CrossRef] [PubMed]

43. Forest Survey of India (FSI). India State of Forest Report; Ministry of Environment and Forests: Dehradun, India, 2011.

44. Richards, J.A. Remote Sensing Digital Image Analysis, 5th ed.; Springer: Heidelberg, Germany, 2006.

45. Congalton, R.G. A review of assessing the accuracy of classifications of remotely sensed data. Remote Sens. Environ. 1991, 37, 35-46. [CrossRef]

46. Perez, M.J.; Kobayashi, H.; Matsumura, I. Analysis of land use change in Comayagua County, Honduras, based on remote sensing and field survey data. J. JASS 2005, 21, 199-208.

47. Shalaby, A.; Tateishi, R. Remote sensing and GIS for mapping and monitoring land cover and land-use changes in the Northwestern coastal zone of Egypt. Appl. Geogr. 2007, 27, 28-41. [CrossRef]

48. Vogt, P.; Riitters, K.H.; Estreguil, C.; Kozak, J.; Wade, T.G.; Wickham, J.D. Mapping spatial patterns with morphological image processing. Landsc. Ecol. 2007, 22, 171-177. [CrossRef]

49. Uddin, K.; Chaudhary, S.; Chettri, N.; Kotru, R.; Murthy, M.; Prasad, R.; Ning, W.; Man, S.; Krishna, S. The changing land cover and fragmenting forest on the Roof of the World: A case study in Nepal's Kailash Sacred Landscape. Landsc. Urban Plan. 2015, 141, 1-10. [CrossRef]

50. Puyravaud, J.P. Standardizing the calculation of the annual rate of deforestation. For. Ecol. Manag. 2003, 177, 593-596. [CrossRef]

51. Pandit, M.K.; Sodhi, N.S.; Koh, L.P.; Bhaskar, A.; Brook, B.W. Unreported yet massive deforestation driving loss of endemic biodiversity in Indian Himalaya. Biodivers. Conserv. 2007, 16, 153-163. [CrossRef]

52. Sharma, M.; Areendran, G.; Raj, K.; Sharma, A.; Joshi, P.K. Multitemporal analysis of forest fragmentation in Hindu Kush Himalaya: A case study from Khangchendzonga Biosphere Reserve, Sikkim, India. Environ. Monit. Assess. 2016, 188. [CrossRef] [PubMed]

53. Tiwari, P.C. Land-use changes in Himalaya and their impact on the plains ecosystem: Need for sustainable land use. Land Use Policy 2000, 17, 101-111. [CrossRef]

54. Qasim, M.; Hubacek, K.; Termansen, M.; Khan, A. Spatial and temporal dynamics of land use pattern in District Swat, Hindu Kush Himalayan region of Pakistan. Appl. Geogr. 2011, 31, 820-828. [CrossRef]

55. Nandy, S.; Kushwaha, S.P.S.; Dadhwal, V.K. Forest degradation assessment in the upper catchment of the river Tons using remote sensing and GIS. Ecol. Indic. 2011, 11, 509-513. [CrossRef]

56. Geist, H.J.; Lambin, E.F. What Drives Tropical Deforestation; A Meta-Analysis of Proximate and Underlying Causes of Deforestation Based on Subnational Case Study Evidence; LUCC Report Series 4. Land-Use and Land-Cover Change Project; CIACO: Louvain-la-Neuve, Belgium, 2001; Volume 1.

57. Munsi, M.; Malaviya, S.; Oinam, G.; Joshi, P.K. A landscape approach for quantifying land-use and land-cover change (1976-2006) in middle Himalaya. Reg. Environ. Chang. 2010, 10, 145-155. [CrossRef]

58. Zomar, R.J.; Ustin, S.L.; Carpenter, C.C. Land Cover Change along Tropical and Subtropical Riparian Corridors within the Makalu Barun National Park and Conservation Area. International Mountain Society. Mt. Res. Dev. 2016, 21, 175-183. [CrossRef] 
(C) 2017 by the authors. Licensee MDPI, Basel, Switzerland. This article is an open access article distributed under the terms and conditions of the Creative Commons Attribution (CC BY) license (http:/ / creativecommons.org/licenses/by/4.0/). 